\title{
Limit and Creation. Towards an Ethic of Self-Limitation in the Digital Era
}

\author{
Alessandro De Cesaris \\ (University of Eastern Piedmont, Italy, alessandro.decesaris@gmail.com)
}

In this article I would like to give an answer to the following question: how can we be creative today? The question concerning creativity, though, is at the same time a question concerning future. There is a close connection between future and creativity ${ }^{1}$. Common sense doesn't understand future just as what "comes next" in a hypothetical succession of facts: future, actual future, has to be something new, something never seen before, a true increment of the number of things existing or ever existed. The Italian semiotician and word-puzzle-maker Stefano Bartezzaghi has given a very interesting definition of creativity: "Creativity is to transform the present in order to make future better and to obtain a different future, better just because different" (Bartezzaghi 2013) ${ }^{2}$. The question asked in the beginning becomes then the following: how can we create something new? This question is particularly relevant today. I will argue that our conception of newness has radically changed, and has progressively obtained some features we could call "dialectical". This means that our concepts of creativity, of newness and of future itself are plastic, historical, subject to our society's material and cultural setting. The fact itself that creativity is a value - one of most widespread and undisputed assumption of our era - is not a given, but rather depends on a vast variety of contingent circumstances. If we have to answer to the question concerning creativity, we have to do it starting from today's society. Another interesting element is that the question concerning creativity does somehow imply the problem of freedom, but is rather more specific. One can be free without being creative - at least according to a certain concept of freedom - and there can be freedom without future, but not creativity. That's

1 Franco "Bifo" Berardi (2011) offers a very interesting analysis of the problem of future, with brilliant insight to many matters that will be discussed in this article. His central thesis, that future is somehow exhausted in our digital era, is strictly convergent with the core statements of this essay.

2 There are, of course, other ways to conceive creativity and future. I will focus on common sense precisely to point out that our need is to avoid an increment-based understanding of creativity, and rather focus on a qualitative conception of the notions of „creativity" and „future”. 
why, in my opinion, it is creativity and not just freedom that has to be put in question in order to seriously investigate about our idea of future.

Of course, asking the question implies that there is a problem with creativity. I will start by analyzing some key features of our society with regard to the discussed topic, focusing on three elements - quantity, perspective and distance. I will use my analysis as a basis for an attempt to show why I believe that creativity and future, even though they are at the core of today's rhetoric, are actually in danger.

After that, I will try and suggest a possible way out by sketching the outlines of an "ethic of self-limitation" as an alternative to the kind of uncreative freedom I individuate as a core aspect of our present condition. Finally, I will argue that the aesthetics endorsed by the authors of Oulipo (Ouvroir de littérature potentielle) can be interpreted as an interesting predecessor of my proposal.

\section{Quantity, Distance, Perspective. Outlines of Hypermodern Society}

A key feature of the present time for western societies is the passage from a post-modern to a hyper-modern condition. The prefix hyper- has been widely used in social sciences (Han 2014; Morton 2014, Sloterdijk 1995; Codeluppi 2012) ${ }^{3}$, even though with different aims and meanings, but is always meant to indicate an actual paradigm shift. Postmodernity had been defined basically through negative features: end of big narratives (Lyotard 1979), erosion of some forms of belief that were typical in modern societies (Vattimo 1999), exhaustion of linguistic and artistic resources (Barth 1967, Eco 1983). On the contrary, it is interesting to remark that hypermodernity is defined positively through a set of features that can all be linked to technology and to the socalled Information Revolution (Floridi 2014).

The first core feature is quantity. In 2013 Google processed about twenty Petabytes (every Petabyte is a million of Gigabytes) of data every day. That's about twice the space used by Youtube to store all its videos, or twenty times the space used by the US government to store the data of the census from 1790 to 2000. Borges' dizzying reveries about Babel Library are now not only actual, but even obsolete: we are now able to store not only texts, but also numbers, images, songs, videos 4 .

All this is something quite different from the quantitative aspect of modernity many interpreters and intellectuals underlined and criticized. The hypermodern "Reign of Quantity" does not prefer quantity over quality, but

\footnotetext{
${ }^{3}$ I would like to point out that I use the term "hypermodernity" without any relation to the way it has been used by Paul Virilio and some other French thinkers (Lipovetsky, Serroy) during the last decades.

${ }^{4}$ The data are taken from Gunelius (2014).
} 
rather shows that quantitative difference is at the same time qualitative ${ }^{5}$. Paraphrasing Hegel, quantitative transitions to qualitative, or, as someone recently wrote: "More isn't just more. More is different" (Anderson 2008). All this has some very remarkable consequences.

In 2008 Chris Anderson, Wired's chief editor, wrote an article entitled The end of theory. The data deluge makes the scientific method obsolete (Anderson 2008). According to Anderson we always had to elaborate theoretical models in order to select data and get results through approximation. Today, though, we do not need selection or approximation anymore, since we are in possession of informatic instruments able to process a huge quantity of data, and to interpret them individually. For this reason, traditional scientific method is doomed: a new setting appears, where it is not the model that makes data interpretable, but it's rather data themselves that generate the model. According to Anderson, if "old" science was always oriented and originally tainted by some sort of bias, the new science of big data is agnostic: when facing the totality of data, we don't need cuts, selections or orientations anymore. We just need data.

Anderson writes: "This is a world where massive amounts of data and applied mathematics replace every other tool that might be brought to bear. Out with every theory of human behaviour, from linguistics to sociology. Forget taxonomy, ontology, and psychology. Who knows why people do what they do? The point is they do it, and we can track and measure it with unprecedented fidelity. With enough data, the numbers speak for themselves".

The new science of big data contradicts Aristotle's famous statement, according to which there is only science of the universal. As the new personalized advertisement system on Google and Facebook shows, we have finally reached the science of the individual. In a formula, with the "Fourth Revolution" we have got to the point where the map and the territory are finally one. In this new science correlation substitutes causality ${ }^{6}$, and we have a complete, a-perspectival knowledge of data7.

The lack of perspective is the second key feature of hypermodernity, an aspect to which Korean-German philosopher Byung-Chul Han has given much attention. Modern society, based on biopolitical forms of control, was

5 The reference is to Guenon (2004). Understanding the difference between a quantitative society and a society where "quantity is quality" is fundamental in order to grasp the difference between modernity and hypermodernity.

${ }^{6}$ It is interesting to remark that this was exactly August Comte's hope about sciences in general, and social sciences in particular. The positive step of every science is reached exactly when we don't try to explain phenomena through causality anymore, but simply through correlation (see Comte 1830, 4).

7 Since its publication, Anderson position has of course been widely discussed and criticized. What is interesting, though, is that such claims - until a few decades ago only possible in a sci-fi novel - are now possible in a serious scientific debate. For a deeper, updated and complete account of the question see Meyer-Schönberger and Cukier (2013). 
dominated by the idea of the panopticon. Now instead we live in a society where the purely numeric nature of information, and their elaboration by neutral processors and machines, makes the very idea of a perspective - even though "total" - obsolete. Some philosophers (Ferraris 2015) have mentioned the Hegelian absolute: the idea of a "pure" knowledge takes shape in a kind of science based on big data. This global and a-perspectival knowledge leads to the idea that Infosphere is some sort of "connective unconscious": just like the old theological image of a hidden, all-knowing god, today we make the unsettling experience of a system that seems to know us better than we don't know ourselves (DeKerchove 2015).

Immediately linked with the lack of perspective is the absence of distance, spatial and temporal. New hypermodern society doesn't rely much on the idea of bigger space and lesser times, but rather on the complete override of the notion of space and time itself. Instantaneousness dominates new technologies, and the instant is precisely what is outside of time. Distances are not simply reduced, they are made completely obsolete. What Marshall McLuhan indicated with the idea of an "imploded world" is now becoming real (McLuhan 1964). The notion of "global village" describes with accuracy this dimension: our global hypercommunity is based on a new form of mediatic orality, where every meeting and common experience is made possible by the sharing of a same non-space and non-time.

The overriding of spatial and temporal distance doesn't imply that space and time are obliterated, just like the transition of quantitative to qualitative doesn't eliminate quantity. Our hypermodern society is dominated by a logic of addition, of constant quantitative increase (Han 2014). The formula "more isn't just more, it's different" must not let us forget that we are only talking about quantity, such a quantity that no finite mind can possibly deal with it. Our global village is immense and inexhaustible, it has more huts than we will ever be able to visit individually (as anyone who has subscription to Netflix knows too well). Some months ago a game entitled No Man's Sky has been published. The game has been widely advertised by mentioning its most incredible feature: the player explores a universe made by more than 8 billions of billions of planets, a universe that will never fully discovered by any individual player. In its title No Man's Sky expresses the essence of our reality, that is not man-oriented anymore ${ }^{8}$. Anthropocene is dominated by this fascinating contradiction: man has finally shaped the universe in his own image, but at the same time the society we live in seems to have reached a dimension that overpowers us 9 .

${ }^{8}$ A very similar idea has been expressed by the acclaimed movie Her (2013).

9 The origin of this idea is, of course, Ray Kurzweil's concept of singularity (see Kurzweil 2006). 


\section{Hypermodernity and Creativity}

This analysis wasn't meant to be either optimistic or pessimistic. The alternative between enthusiasm and scepticism can be avoided by assuming a critical stance, and this in the Kantian sense: what we need in fact is to determine the conditions of possibility and the limits of today's condition. The main of condition of possibility, as seen, is given by the new technologies now massively operative in every heavily industrialized society. The main focus though are the limit, since it's here that the topic of this article appears again. Paradoxically, the main and most apparent limit of hypermodern society is the absence of any other limit.

The override of spatio-temporal distance has an immediate effect: the disappearance of future. The widespread slogan "Future is now" is not only brilliant, but also surprisingly true. Our present is utopian because it is nonspatial, but is also chronical because our increased ability to predict the future allowed us to implement it in our present, to make it part of our life almost as if it were already actual. In a formula, future is already past.

The first side-effect of our present obsession with the future is that the constant irruption of new devices and products is almost taken for granted. There is such a huge quantity of new things flowing in our experience everyday - and often at a very-well established pace - that we are hardly surprised by anything anymore. The huge spread of creative jobs, the celebration of originality at every cultural and productive level (from Kickstarter to contemporary art, from cinema to videogames) creates a paradoxical situation: we crave for newness, but there is nothing new about new. There are no limits to progress, to increase or to the potentialities of technology, at the point that any new product is something trivial, something largely predictable.

The implementation of future in our present is one of the major risks and problem of hypermodern society. The expression "the present is pregnant with the future" states now an unsettlingly literal truth, i.e. that our future is now fallen into line with what already exists. Dominque Cardon (2015) underlined this problem talking about the algorithms used to process big data, since they tend to flatten any projection on what has already happened: Amazon suggests what has already been bought or is similar to what we have already been bought, or different according to strictly predetermined parameters.

There is nothing we can't do, and yet whatever we do has somehow already been done. That's why in this society filled with creativity it is incredibly difficult to be creative. This also modifies our conception of freedom. The contraposition between negative and positive freedom is well established in our philosophical lexicon. And yet, both forms of freedom are possible in a setting where any kind of newness is excluded: the elimination of any obstacle to the free choice of individuals is not a problem, since our society doesn't 
express control in the form of prohibition anymore (Han 2016). In the same way, positive freedom to do something remains subject to the paradigm of choice between given alternatives: we are free to choose from a huge variety of options, but none of this can be compared with what tradition has given us under the name of creation. This is another feature of hypermodern society: creation is a non-creative process.

A last problem rises from the last key feature mentioned, that is the lack of distance. The absence of distance comes together with the crisis of one of the most important paradigms of modernity, the distinction between subject and object. Postmodernism has largely criticized the notion of subject. Hypermodernity, on the contrary, shows that it is the notion of "object" to be problematic. Many authors (Latour 2005, Sloterdijk 2009) underlined how difficult it is to distinguish between subject and object in our present era. A reason for that is that it is quite hard to find an object that doesn't possess, at some level, a kind of subjectivity (let's think about Internet of things) or that doesn't become constituent part of a subjectivity (our smartphones are a good example). The complete absence of distance between us and the prostheses and devices we use is problematic because it is a pre-conscious relationship. Technology is a second nature because it is a form of artificial immediacy, a condition in which we don't apply any distance between us and objects. The critical category of "reification" expresses the idea that the object dominates us, shapes us no less than we shape the object itself. In a formula: we don't use technology, but we are immersed in it (Ippolita 2012). Our ability to metabolize and internalize the use of devices up to making it natural makes us free and powerful, but channels our possibilities of action in a pattern that has already been pre-determined by devices themselves. Again, this does not necessarily have to be bad: what is evident, though, is that the only true creative subject is the scientific-technological apparatus as a whole. McLuhan was right again: technology seems to be the true subject of history.

\section{Creativity and Self-Limitation}

It is now time to get to the pars construens of the article, and to answer to the question: how can we be creative today? I have argued that the absence of limits is the main limit to creativity of our society. I will suggest that the restoration of limit is a possible answer to our question. First of all a clarification is needed: my answer is oriented toward an individual ethics, whose main aim is to preserve a certain possibility for human experience. Just like my analysis of hypermodern society, also my proposal for an individual ethic of limit is articulated in three points.

Firstly, in order to limit quantitative hypertrophy we need a qualitative limit. This is very important, since my proposal has very little to do with degrowth, 
but rather focuses on a qualitative reorientation of life. Minimalism is focused on the idea of a quantitative limit, whereas an ethic of self-limitation endorses the idea of a qualitative criterion of selection for any content, object or task we want in our life. The experience of newness, in this sense, does not rely anymore on the concept of something "more" coming into our life, but rather on the idea of a personal rearrangement of what already is. According to this new stance, more is just more: what is different, on the contrary, is our selection, disposition and use of the existent.

The second important aspect is the recovery of distance. In order to reacquire an objective, thus conscious and aware relationship with technology and with the devices we use to act and think, we need set a distance between us and those devices ${ }^{10}$. This means first of all that it is necessary to acquire some minimal competencies about the devices we use, but also that we have to be able to experience life without them in order to grasp the difference. The aim of an ethic of self-limitation is to make our relationship with technology something more than an automatism, and thus to make us able to act on technology as well as through it.

Finally, we need to reacquire perspective, or the ability to have an individual perspective: the advent of the Absolute dreamed by some philosophers means somehow the end of the human dimension of existence. In this sense, the reacquisition of a perspectival dimension allows us to reacquire a creative stance towards experience. Of course this has nothing to do with perspectivism: to reacquire perspective doesn't mean to promote subjective opinions over truth, or partiality over impartiality. It simply means to preserve full awareness of one's own position in the world, along with the ability to elaborate this position independently.

These three aspects go somehow together. We are can't really operate a selection and limit our fruition of products without acquiring competencies and setting a distance between us and media or products. At the same time, operating such a selection is precisely what makes our perspective individual.

Now, one could ask if such an ethic already exists. I would like to suggest that the demands I just listed are at the core of a French and Italian literary current started in the middle of last century. The Oulipo (Ouvroir de littérature potentielle) was founded in 1960 by Raymond Queneau and the mathematician Jacques Roubaud, and with an aim very similar to that I have outlined in these pages. Surrealism had endorsed an idea of artistic creativity that was founded on some quite interesting principles: abolition of the separation between subject and object (celebration of dream and of subconscious); complete absence of spatial, stylistic and lexical limits, up to

10 This problem is particularly important with regard to new generations. Digital natives are in fact completely submerged in digital technology, but at the same time show much less awareness that those who experienced the diffusion of personal computers, mobile phones or the Internet. On the topic see Thomas 2011. 
the point to be allowed to write meaningless texts; depersonalization of the author (automatic writing). It's easy to see that these principles look very alike the three basics of hypermodern society (quantity, distance, perspective). Queneau's main idea was that writers, when left completely free and without any limit, are subject to a great deal of automatisms (Queneau was the editor of Kojève's lectures on Hegel, and knew very well the notion of second nature). According to Queneau, the idea of spontaneity is substantially a myth.

Against this paradigm of creativity, Queneau elaborates a theory that is radically different, and is based on the notion of contrainte, that is a selfimposed limitation. According to this method the writer arbitrarily chooses its own limits, he writes on the basis of completely external rules, without any relation to its style or intention. The result, according to Queneau, is a superior awareness in writing, the liberation of language from automatisms and the use of authentically creative processes. As Queneau writes: "The classical writer that writes his tragedy observing a certain amount of rules he knows is more free than the poet who writes whatever comes to his mind, and who is slave of other rules he ignores" (Queneau 1981) ${ }^{11}$.

Here Queneau is talking about freedom, not about creativity. A reason for that is that Queneau keeps some Hegelian points of view with regard to practical philosophy. Anyway, his discourse can be extended to creativity as well: any creative act is made possible by a form of subjectivation that finds its core in establishing a limit. In this case there can still be freedom because it is a form of self-limitation, an autonomous act. Paradoxically, it is exactly the lack of limits that is forced onto us by society: the specific condition of our age forces us to redefine some categories and some classical positions. Subjectivation in itself is an act of self-limitation: by choosing our own limits, we refuse those imposed externally by our social context.

Oulipo's stance is really peculiar. Contemporary literature often criticizes society in its content, but duplicates it in the form. The idea of "maximalist novel" (Ercolino 2014) basically indicates a work that is hypertrophic and exceeds any given classical structures, and is generated through a logic of addition. Maximalist novel looks very much alike the world it describes: Oulipo's novels don't look like anything. Let's see, as an example, the novel $A$ Void (La disparition) by Georges Perec. The novel is quite famous because it has been entirely written without ever using the vowel "e". Even though the work doesn't touch social or political topics, it is evident that Perec's aim is ethical: in the afterword to the novel he writes that such a choice is an attempt to free and rescue language. This is at the same time an attempt to react to postmodernism, that is the idea that "everything has already been written". Perec's problem is precisely our problem: how to be creative in a setting

${ }^{11}$ My translation (see also Calvino 1988). 
where there is no possibility for new words, new plots, new characters ${ }^{12}$ ? Perec's response doesn't rely on the content, but rather on the very form of writing and of artistic creation in itself. In the same way, an ethic of selflimitation is not based on any kind of "maxim", does not offer any determinate rule. On the contrary, it endorses the idea of rule in itself, the need to switch our focus from contents to criteria used to select those contents ${ }^{13}$.

Let's consider our initial question once again: how do we create something new? It is clear that we must first of all ask ourselves: what do we mean by "new"? According to the definition we have given above, there is a strict relationship between "new" and "more": we create something new only insofar we create something "more" than what already exists. But is this necessary? As it has been shown, it is precisely this relationship between "new" and "more" that has to be put in question in order to understand the difficulties of today's society.

\section{Conclusion}

Oulipo's poetics can teach us something about how to live creatively in a world suspended between the constant, passive irruption of new possibilities and the exhaustion of actual resources and ideas. The shift from quantity to quality is related with the need to focus our attention not just on the contents, but also on the form, i.e. on the way these contents are experienced, selected, used. This means that we must abandon the idea that a creative act is just the production of something new, and understand it rather as a reorientation, a selection of an individual path in a given set of possibilities.

As already pointed out, this proposal is only consistent as a form of individual ethic. There are already many public debates about the need to set new limits for scientific research, for technological production, for publication or fruition by the masses. These debates are not object of this article, since here the main focus is on the attempt to preserve a kind of experience, along with a certain way to live. From this standpoint, this ethic must be understood first and foremost as an ethos, a way of life, whose main aim is aesthetic much more than "moral" (even though, of course, creativity is in this case implicitly understood as an intrinsic value).

\footnotetext{
${ }^{12}$ At the same time, it is interesting to point out that there is another problem, opposite to this: how to be creative in a setting where there are infinite words, plots, characters, elements to choose among? Oulipo's approach is impossible in world featuring infinite possibilities. That's why the first necessary step is to show that this (quantitative) infinity is more a boundary than an enhancement to creativity.

13 It is interesting to remark that Hegel shared a similar suspect toward "new" contents, and emphasized in the same way the importance of paying attention to the form (see Hegel 2008, 4).
} 
A last element to consider is the account of digital age that has been given. The aim of this paper was not to depict our era as an age of crisis and despair: the paradoxical condition of creativity is one problematic aspect of a time that, just like every time, has its own distinctive elements, its potentialities and its limits. It is not necessary for everyone to be creative. And yet, it is fundamental to grasp what it means to be creative in a given time, and how to be it.

\section{Literature}

Anderson, Ch. 2008. The End of Theory: The Data Deluge Makes the Scientific Method Obsolete, available at <https://www.wired.com/2008/06/pbtheory/> (last visit 12.04.2017).

Bartezzaghi, S. 2013. Il falò delle novità. La creatività al tempo dei cellulari intelligenti. Torino: UTET.

Barth, J. 1967. The Literature of Exhaustion. In Id., The Friday Book: Essays and Other Non-Fiction. London: John Hopkins University Press, pp. 63-76.

Bifo Berardi, F. 2011. After the Future. Chico (CA): AK Press.

Calvino, I. 1988. Six Memos for the Next Millennium. New York: Penguin Books.

Cardon, D. 2015. A quoi rêvent les algorithmes. Nos vies à l'heure. Paris: Seuil.

Codeluppi, V. 2012. Ipermondo. Roma-Bari: Laterza.

Comte, A. 1830. Cours de Philosophie Positive. Paris: Bachelier.

De Kerckhove, D. 2015. La rete ci renderà stupidi? Roma: Castelvecchi.

Eco, U. 1983. Postille a "Il Nome della rosa". In Id., Il Nome della Rosa. Milano: Bompiani, pp. 381-403.

Ercolino, S. 2014. The Maximalist Novel: From Thomas Pynchon's Gravity Rainbow to Roberto Bolano's 2666. London: Bloomsbury.

Ferraris, M. 2015. Mobilitazione totale. Roma-Bari: Laterza.

Floridi, L. 2014. The 4th Revolution. Oxford University Press.

Guenon, R. 2004 (1945). The Reign of Quantity and the Signs of Time. New York: Sophia Perennis.

Gunelius, S. The Data Explosion in 2014 Minute by Minute, available at $<$ https://aci.info/2014/07/12/the-data-explosion-in-2014-minuteby-minute-infographic/> (last visit 14.04.2017).

Han, B.-C. 2014. Psychopolitik. Neoliberalismus und die neuen Machttechniken. Berlin: S. Fischer Verlag.

Hegel, G.W.F. 2008. Outlines of the Philosophy of Right. Oxford: Oxford University Press.

Ippolita, 2012. Nell'acquario di Facebook. La resistibile ascesa dell'anarcocapitalismo. Milano: Ledizioni.

Ippolita, 2015. Anime Elettriche. Milano: Jaca Book.

Kurzweil, R. 2006. The Singularity Is Near. New York: Penguin Books.

Latour, B. 2006. Nous n'avons jamais été modernes. Essai d'anthropologie symétrique. Paris: La Découverte. 
Lyotard, F. 1979. La condition postmoderne. Paris: Minuit.

McLuhan, M. 1964. Understanding Media. New York: McGraw-Hill.

Meyer-Schönberger, V. \& Cuckler, K. 2013. Big Data: A Revolution That Will Transform How We Live, Work and Think. London: John Murray.

Morton, T. 2014. Hyperobjects. Philosophy and Ecology After the End of the World. Minneapolis: University of Minnesota Press.

Perec, G. 1990. La disparition (1967). Paris: Gallimard.

Queneau, R. 1981. Segni, cifre e lettere. Torino: Einaudi.

Sloterdijk, P. 1995. Im selben Boot. Versuch über die Hyperpolitik. Frankfurt/M.:

Suhrkamp.

Sloterdijk, P. 2009. Du musst dein Leben ändern. Über Anthropotechnik. Frankfurt a.M.: Suhrkamp.

Thomas, M. (ed) 2011. Deconstructing Digital Natives. Young People, Technology and the New Literacies. New York: Routledge.

Vattimo, G. 1999. La fine della modernità. Milano: Garzanti. 


\title{
Alessandro De Cesaris \\ (University of Eastern Piedmont, Italy, alessandro.decesaris@gmail.com)
}

Limit and Creation Towards an Ethic of Self-Limitation in the Digital Era.

\begin{abstract}
Aim of this article is to analyse the relationship between creativity, freedom and future in contemporary society. The main focus is on the notion of creativity in our digital era. Common sense understands creativity as a concept implying something new, something original that did not exist before. And yet in our society the constant overflow of news, products and contents doesn't surprise anymore, is no longer connected to a truly creative act. The complete lack of limits seems to be our society's own limit, since newness is not experienced anymore as something really new. The solution to this situation is a new ethic of self-limitation that reshapes our idea of creativity and bases it on different criteria. The first part of the article is an analysis of hypermodern society. Hypermodernity is defined through three features: quantity as a qualitative element, override of distance, sublation of perspective. Unlike postmodern society, hypermodernity defines itself positively on the basis of some technological and social results that are experienced as improvements. In the second part of the article the paradox of hypermodern society is discussed: despite its obsession for newness, despite the huge spread of creative jobs and the passion for future, newness seems to be something given and usual, being creative means conforming to given standards, and future is almost completely implemented into present. In the last part of the article I argue that a solution to this situation is an ethic of selflimitation, in which a rediscovery of limit leads to a new concept of creativity no longer based on quantitative increment, but rather on the ideas of qualitative selection, objective distance, personal perspective. According to this view, being creative is no longer a matter of content, but rather of form. I will also argue that the aesthetics of Oulipo, a French literary movement of the Sixties, already expressed this stance in a very similar situation.
\end{abstract}

Keywords: technology, second nature, creativity, freedom, media, Oulipo.

Ethics in Progress (ISSN 2084-9257). Vol. 8 (2017). No. 1, Art. \#6, pp. 89-100.

Creative Commons BY-SA 3.0

Doi: 10.14746/eip.2017.1.6 